\title{
The Evaluation of Negative Anthropogenic Factors Subjection on Bolts Stability and Surrounding Massif Deformations
}

\author{
Alexey A. Renev \\ T.F. Gorbachev Kuzbass State \\ Technical University \\ Kemerovo, Russia \\ raa@kuzstu.ru
}

\author{
Sergey S. Tsibaev \\ T.F. Gorbachev Kuzbass State \\ Technical University \\ Kemerovo, Russia \\ cibaevss@kuzstu.ru
}

\author{
Stepan I. Kalinin \\ Scientific Research and Engineering \\ Design Department «Ugolnye \\ Tehnologii Kuzbassa», \\ Prokopevsk Department of Kuzbass \\ State Technical University \\ Prokopevsk, Russia \\ niutk@yandex.ru
}

\begin{abstract}
Herein there are the results of a tool and visual assessment of condition of excavations, border massif of rocks and anchor support elements influenced by flooding and further drainage, seismic and shock waves dynamic loading and high temperature short-pulse. The extent and term of the mine being under flooded condition has been determined. The results of the durability tests of an-choring rods of various profiles are given for the roofs and sides of the mine working. It has been figured out that distribution of probability of the hardening force of the anchors in blast-holes in the roof of the mine working meets the normal law of distribution. There are analyzed results of radar shooting of the roof taken by georadar OKO-2's. It has been figured out that the height of rock breaking of the roof of the mine working changes 0.2 to $2.25 \mathrm{~m}$; comparison to the theoretical height of the roof arch has been made. The assessment of tendency of the coal massif to water saturation has been made, the height of water saturation of the roof rocks has been determined. It has turned out that that the height of moistening depends on the arch stability of rocks formed during the time of test. It has been determined that water saturation of the rocks leads to decrease in specific cohesion of the fastening structure of chemical ampoules with shot walls. Ascertain the values of seismic waves speed propagation from blasting, oscillation speed, displacements and relative de-formations of rock massif.
\end{abstract}

Keywords-underground mining, the maintenance of mine workings, bolt, flood, explosion, resistance, seismic wave, shock wave

\section{INTRODUCTION}

The accident on «Raspadskaya» coal mine (Russia, Kemerovo region) in May of 2010's had not only loss of life's but also damage an enormous mine workings. As a result of flooding and further drainage, seismic and shock waves dynamic loading a majority of workings support was damaged. Also there was 13 accidents on Kuzbass coal mines with human victims over the past 20 years. A lot of these accidents caused by methane and coal dust blasts connected with seismic and shock waves spreading and high temperature short-pulse in the area of the explosion. The spontaneous flooding of the mines often use for accident elimination at fire formation.
Above-described a long-time mine workings maintaince, supported by bolts, and subjection of negative anthropogenic factors on bolts stability and surrounding massif deformations problems are poorly studied and has a high relevance for future investigations..

\section{BACKGROUND}

The research objects was elements of anchorage and surrounding massif. It was based on PJSC «Raspadskaja ugolnaja kompanija» and OJSC «SUEK-Kuzbass» pits conditions.

There was mine workings located on 3-3a, 7-7a, 9, 10 working seams within the research program on «Raspadskaya» coal mine. The total length of surveyed workings was about $60 \mathrm{~km}$. The «Raspadskaya» coal mine mine workings was subjected by seismic waive twice: first time - as a result of methane blast (the volume of gas was about $600 \mathrm{~m} 3)$ in a pillar 5a-6-18 goaf near the breakthrough 5 (fig $1,2,3$ )

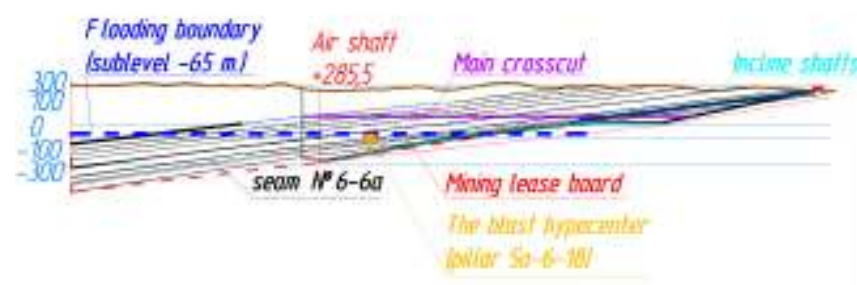

Fig. 1. The location of explosion hypocenter on opening scheme 


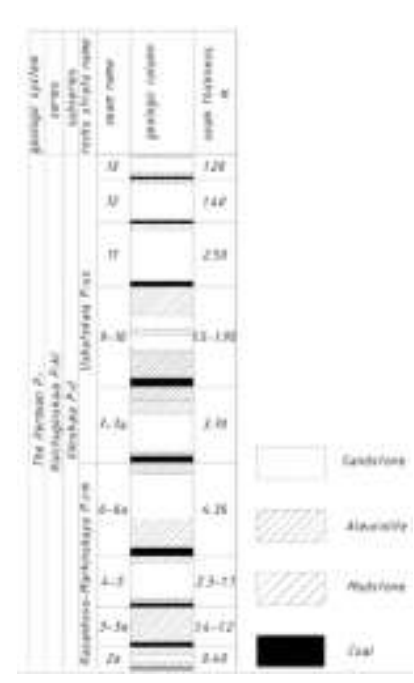

Fig. 2. The Raspadskaia mine stratigraphy

May 82010 at 11:55 p.m.; second time - May 92010 at 03:55 a.m. as a result of huge deposits of coal dust blasting located on a mine workings surface in mining district №8 the infinite beam was only subjected to uniform load, the static equilibrium relationship can be known [20]:

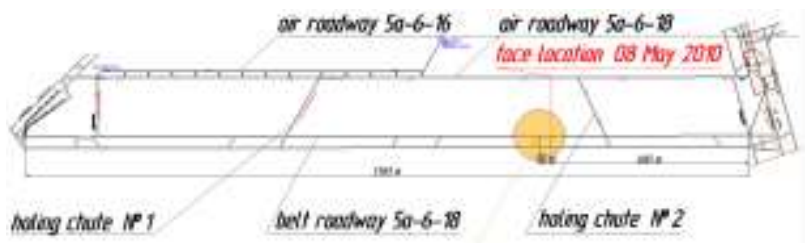

Fig. 3. The location of explosion epicenter on mine map (pillar 5a-6-18)

\section{FIELD MEASUREMENT}

Besides subjection of seismic wave, mine working was subjected by direst and reflected shock waves. In ended up with more than $300 \mathrm{~km}$. of miny workings were subjected by dynamic loading. From a total length, 39 mine workings were flooded. The total length of flooded workings as 20.2 km. (fig. 4).

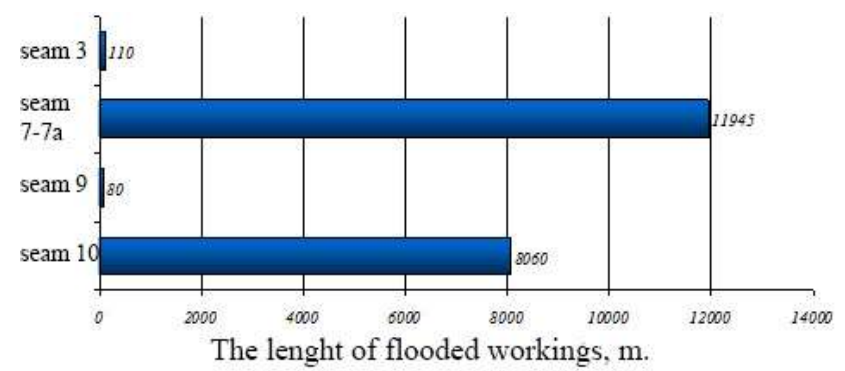

Fig. 4. The distance allocation of flooded mine workings according location

The survey was conducted according the methodology [1] and federal law $[2,3,8]$. The working group estimate real state did drawings, measurement and finally prepared the certificate of inspec-tion for each mine workings survey. The anchorage elements was evaluated visually, the tightening torque of nuts was checked by torque wrench KDM-5. The bolts was loaded by hydraulic jack PKA-1 of PKA-3. The mine workings dimensions were measured by roulette of supersonic meter.

The evaluation of working flooding on bolts stability and surrounding massif deformations was estimated by bolts loading and by the comparison of real specific cohesion of the fastening structure of chemical ampoules with shot walls and bolts. Using the real data of specific cohesion of the fastening structure of chemical ampoules with shot walls it could be possible to estimate surrounding massif conditions. Using the real data of specific cohesion of the fastening structure of chemical ampoules with bolts it could be possible to estimate fastening structure properties. In addition there were analyzed results of radar shooting of the roof taken by georadar OKO-2's [4].

The statistical series was received as a result of bolt loading series in roof and wall of workings located on 3-3a, $7-7 \mathrm{a}, 9,10$ working seams. After that was drawed bolts loading distribution lines. It has been established that the probability of bolts force fastening described by normal distribution law:

$$
P_{i}=\frac{1}{\sigma_{x} \cdot 2 \pi} \cdot e^{-\frac{\left(x_{i}-m_{x}\right)^{2}}{2 \sigma_{x}^{2}}}
$$

In the type: $\sigma_{x}-$ the standard deviation of loading; $x i-$ the loading force; $\mathrm{m}_{\mathrm{x}}$ - the mathematical expectation (average value).

The mine workings roof supported by steel bolts with inch (AV-20 type) or metric (ASP-20 type) threads. Fig 5. illustrates the roof bolts loading distribution line with inch thread in the holes. The mathematical expectation was 97,05 $\mathrm{\kappa H}$, standard deviation was $8,25 \mathrm{\kappa H}$. The mathematical expectation of metric thread roof bolts was 73,05 кH, standard deviation was 7,69 кH. The differ-ence between mathematical expectation values of inch and metric threads bolts in roof explained by the fact of different maximum breaking load of steel armature with various threads.

The mine workings walls supports by steel bolts (AVR16, AVR-20, ASP-20 types) and expan-sion bolts (SHK-1M type). The mathematical expectation of steel metric thread walls bolts was $45,37 \mathrm{\kappa H}$, standard deviation was 9,44 кН. The difference between mathematical expectation values of inch threads bolts in roof and walls explained by the fact of different fastening length using chemical ampoules with polyurethane compound. According Russian Technical rules [2], the minimum fastening length for roof bolts is $0.9 \mathrm{~m}$., for walls bolts if $0.45 \mathrm{~m}$.

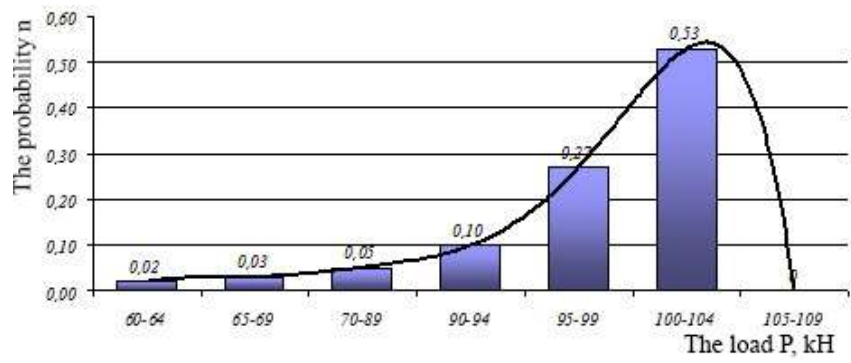

Fig. 5. The steel bolt (inch thread) loading distribution line in workings roof 
Using the mathematical expectation values it could be possible to determine the specific cohesion of the fastening structure of chemical ampoules with shot walls and bolts. The specific cohesion of the fastening structure of chemical ampoules with shot walls can be determined by this way:

$$
\tau_{\mathrm{h}}=\frac{m_{x}}{\pi \cdot d_{\mathrm{h}} \cdot l \cdot K}
$$

The specific cohesion of the fastening structure of chemical ampoules with bolts can be deter-mined by this way:

$$
\tau_{\mathrm{b}}=\frac{m_{x}}{\pi \cdot d_{\mathrm{b}} \cdot l \cdot K}
$$

In the type: $\ell-$ the length of bolt fastening; $K$ - the coefficient of deteriorating conditions in the holes $(\mathrm{K}=0,6)$; $\mathrm{d}_{\mathrm{h}}$ - the hole's diameter $\left(\mathrm{d}_{\mathrm{h}}=30 \mathrm{~mm}\right) ; \mathrm{d}_{\mathrm{b}}-$ the bolt's diameter $\left(\mathrm{d}_{\mathrm{b}}=20 \mathrm{~mm}\right) ; ; \mathrm{m}_{\mathrm{x}}-$ the mathematical expectation (average value), $\mathrm{\kappa H}$.

The results interpretation of bolts stability was made according to recent investigations [9-14]. The calculation (2, $3)$ results shown in table 1 .

\begin{tabular}{|c|c|c|c|c|c|}
\hline Bolt types & $m_{x}, \mathrm{\kappa H}$ & $\ell,(\mathrm{m})$ & $\tau_{\mathrm{h}}, \mathrm{MPa}$ & $\tau_{\mathrm{b}}, \mathrm{MPa}$ & Notice \\
\hline \multicolumn{6}{|c|}{ Roof rocks } \\
\hline Steel inch thread bolts & 97 & 1 & 1,71 & 2,57 & $\begin{array}{c}\text { In normal conditions: } \\
\tau_{\mathrm{h}}=8,2 \mathrm{MPa} ; \tau_{\mathrm{b}}=8,9 \mathrm{MPa}\end{array}$ \\
\hline Steel metric thread bolts & 73 & 1 & 1,29 & 1,93 & $\begin{array}{c}\text { In normal conditions: } \\
\tau_{\mathrm{h}}=8,2 \mathrm{MPa} ; \tau_{\mathrm{b}}=8,9 \mathrm{MPa}\end{array}$ \\
\hline \multicolumn{6}{|c|}{ Walls rocks } \\
\hline Steel bolts with mixed thread & 45 & 0,5 & 1,59 & 2,38 & $\begin{array}{c}\text { In normal conditions: } \\
\tau_{\mathrm{h}}=2,8-3,4 \text { Мпа; } \tau_{\mathrm{b}}=8,9 \mathrm{MПа}\end{array}$ \\
\hline
\end{tabular}

TABLE I. POLYURETHANE COMPOUND ADHESION WITH HOLE AND BOLT

It is certainly that mine workings flooding reduced the polyurethane compound adhesion with hole and bolts. It has been established that water saturation of surrounding massif can reduce the specific cohesion of the fastening structure of chemical ampoules with shot walls on $80-85 \%$ in workings roof and on $48 \%$ on walls.

The georadar OKO-2's was applied for roof rocks stability and stratification and also for rocks water saturation tendency research. The principle of georadar OKO-2's operation based on radar processes $[4,6]$. The georadar survey made with parallel profiles system. The length of each profile was up to $100 \mathrm{~m}$. The distance between parallel profiles was up to $10 \mathrm{~cm}$. The radargrams compared with mining-and-geological conditions and with visual survey. The most completely georadar survey was made at 4's intervening block of seam №9 [6]. Ac-cording to results of georadar survey, the roof rocks has water saturation tendency in the conditions of «Raspadskaya» coal mine. There are a lot of factors influencing on water saturation degree. But the main factor is moisture capacity connected with natural rock openness. Rock moistening condi-tioned by workings flooding, was the reason of decompression expansion and weakening. Joint sys-tems are closed and surrounding massif becomes more monolithic. But at the same time are decreasing the physical-mechanical properties and friction angle [7, 12]. The main physical-mechanical properties of bedrocks shown in table 2 .

\begin{tabular}{|c|c|c|c|c|c|}
\hline $\begin{array}{c}\text { Physical-mechanical } \\
\text { properties }\end{array}$ & Sandstone & $\begin{array}{c}\text { Sandstone and aleurolite } \\
\text { overlaytion }\end{array}$ & Aleurolite & Clay stone & Conglomerates \\
\hline $\begin{array}{c}\text { Protodiyakonov } \\
\text { hardness }\end{array}$ & $\frac{7 \div 16}{10,6}$ & $\frac{5 \div 14}{7,3}$ & $\frac{1,5 \div 12,0}{6,7}$ & $\frac{3 \div 5}{4}$ & $\frac{7 \div 8}{7,5}$ \\
\hline $\begin{array}{c}\text { Total rock } \\
\text { openness, \% }\end{array}$ & $\frac{1,21 \div 7,1}{3,78}$ & $\frac{0,97 \div 6,45}{3,26}$ & $\frac{0,19 \div 8,11}{4,68}$ & $\frac{2,33 \div 5,71}{4,02}$ & $\frac{3,48 \div 4,26}{3,87}$ \\
\hline $\begin{array}{c}\text { Natural moisture } \\
\text { content, } \%\end{array}$ & $\frac{0,58 \div 2,64}{1,50}$ & $\frac{0,91 \div 3,47}{1,93}$ & $\frac{1,14 \div 3,47}{2,13}$ & $\frac{2,76 \div 3,02}{2,89}$ & $\frac{0,99 \div 1,06}{1,02}$ \\
\hline Water absorption, $\%$ & $\frac{0,34 \div 1,93}{1,15}$ & $\frac{0,67 \div 1,69}{1,19}$ & $\frac{0,35 \div 1,67}{1,03}$ & 2,11 & $\frac{0,9 \div 1,25}{1,07}$ \\
\hline
\end{tabular}

TABLE II. PHYSICAL-MECHANICAL PROPERTIES OF BEDROCKS

The hydrogeological properties of investigated coal seams are differ significantly. Some coal seams are hydrophobic (coal seams №9, 7-7a).

It has been established that flooding of conveyor incline 4-9 lead to roof rocks water saturation mainly extend within natural arch. The average height of water saturation areas was 1,25-1,5 m., the height of roof rocks stratification was uniform thickness - 0,8-1,2 m. [6].

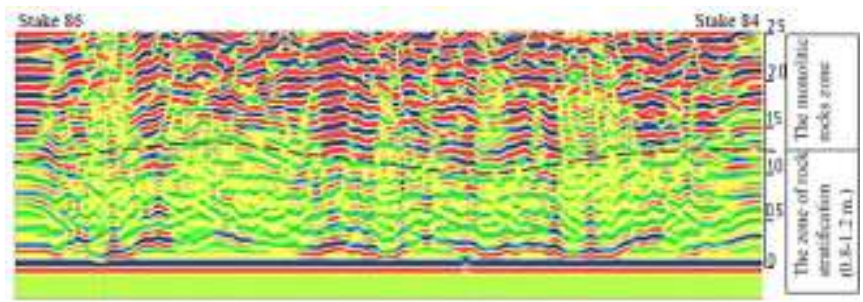

Fig. 6. The radargram of roof rocks at conveyor incline 4-9 (stake 86-84 area) 
The one of the main results of research was high correlation between natural arch height taken by theoretical bases of professor Protodiyakonov and arch height taken by georadar survey (fig. 7). The height of the stratification of rocks in the roof varies from $0,2 \mathrm{~m}$. to $2,5 \mathrm{~m}$, (line 2, fig. 7), the theory-based calculated height of the collapse cave in the roof varies from $0,15 \mathrm{~m}$. to $2,8 \mathrm{~m}$ (line 1 , fig. 7 ).

According to professor Protodiyakonov theory [12] the natural arch height can be determined by this way:

$$
\begin{gathered}
B_{\mathrm{c}}=\frac{(a+c)}{\left(f \cdot K_{c}\right)} \\
c=h \cdot \operatorname{tg} \frac{(90-\varphi)}{(2)}
\end{gathered}
$$

In the type: $\mathrm{Bc}$ - the natural arch height; a - the half width of working; $\mathrm{c}-$ the width of the slide prism; $\mathrm{f}-$ the rock hardness; $\mathrm{Kc}$ - the coefficient of structural weakening of rocks, taking into ac-count the maintaining life of working; $\mathrm{h}$ - the height of working; $\varphi$ - angle of internal friction of rock.

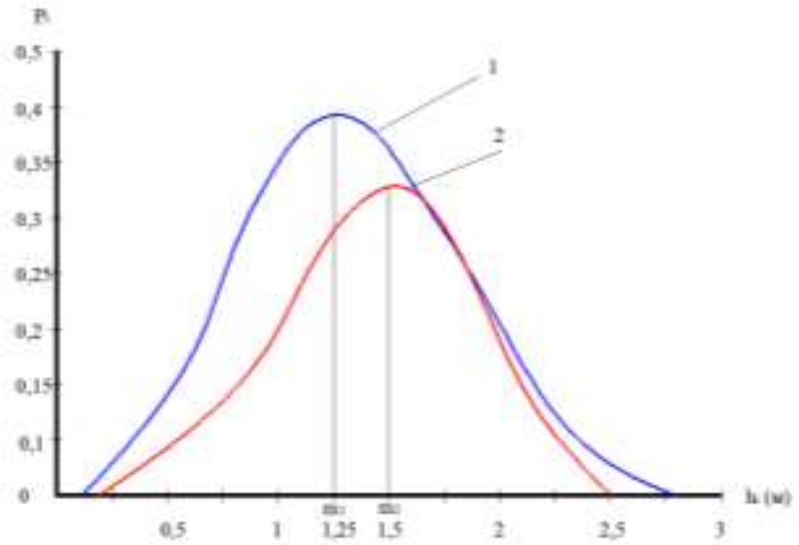

Fig. 7. T Floor arch height distribution lines: $1-$ drawing by a theoretical evaluation: 2 - drawing by radiolocation survey.

It has been confirmed that using georadar survey and radargram designing can identify location of rooks stratification areas, open rock jointing's and cavity's, the water saturation areas, the height of natural arch at surrounding massif.

The elevation of seismic waves subjections on bolts stability and surrounding massif defor-mations were made in the conditions of OJSC «SUEK-Kuzbass» «TaldinskayaZapadnaya-2» coal mine. The anchorage of incline air shaft cyclically loaded by large-scale blasts at « Zarechnyi» coal opencast [15]. The explosive mass for one cycle of blasting is $8000 \mathrm{~kg}$.

The incline air shaft is $2210 \mathrm{~m}$. length and was drivaged from surface to +180 sublevel. It has square cross-section and supported by steel bolts. For elevation of seismic wave's subjections on incline air shaft support was installed observation stations.
The research was conducted according the complex methodology including surface and under-ground observations [15]. The surface observations contain determination of seismic wave's speed and oscillation amplitude from blast epicenter to incline air shaft. The underground observation contain estimation of rock mass stresses around incline air shaft and support load capacity.

The results of seismogram analysis were speed and amplitude-frequency parameters evaluation of seismic waves. The permissible oscillation speed of surrounding massif is one of the most important blasting parameter regulated by Joint Institute's of Physics of the Earth of the Russian Academy of Sciences scale of oscillation intensity [16].

The permissible (maximum) speed of rocks oscillation for underground mine workings, maint-anced more than 5 years, regulated by recommendations [17]:

$$
v_{0}=18,5 \cdot 10^{-7} \cdot v_{p} \cdot e^{\frac{2.3}{1.16^{-T}}}
$$

In the type: $V_{0}$ - the permissible speed of rocks oscillations, $\mathrm{cm} / \mathrm{s} ; \mathrm{V}_{\mathrm{p}}$ - the longitudinal speed of seismic waves, $\mathrm{m} / \mathrm{s}$ (for bed rocks - $3400 \mathrm{~m} / \mathrm{s}$, for coal massif - 2600 $\mathrm{m} / \mathrm{s}) ; \mathrm{T}$ - the incline shaft lifetime, years.

Therefore, the bed rocks permissible speed of oscillations:

$$
v_{0 \mathrm{br}}=18,5 \cdot 10^{-7} \cdot 3400 \cdot e^{\frac{2.3}{1.16^{-9}}}=45, \mathrm{sm} / \mathrm{s} .
$$

Therefore, the coal massif permissible speed of oscillations:

$$
v_{0 \mathrm{c}}=18,5 \cdot 10^{-7} \cdot 2600 \cdot e^{\frac{2.3}{1.16^{-9}}}=35, \mathrm{sm} / \mathrm{s} .
$$

The relative longitudinal deformation of rocks massif caused by maximum speed of oscillations:

$$
\varepsilon=\frac{v_{0}}{v_{p}}
$$

In the type: $\varepsilon$ - the relative deformation; $v_{0}$ - the permissible speed of rocks oscillations, $\mathrm{cm} / \mathrm{s} ;{ }^{v_{p}}-$ the longitudinal speed of seismic waves, $\mathrm{m} / \mathrm{s}$.

The relative deformation of bedrocks:

$$
\varepsilon_{\Pi}=\frac{45}{3,4 \cdot 10^{5}}=1,3 \cdot 10^{-4}
$$

The relative deformation of coal seam №70:

$$
\varepsilon_{\mathrm{y}}=\frac{35}{2,6 \cdot 10^{5}}=1,3 \cdot 10^{-4}
$$

For underground mine working the range of permissible deformation is from $1 \cdot 10-4$ to $5 \cdot 10-4$ [17] For temporary mine workings the permissible deformation can archive greater values. According to importance criteria, all underground mine workings divide in to 4 classes. 
For incline shafts with 89 years lifetime the permissible deformation is $2 \cdot 10-4$ (value for second class of importance). It can by obvious from above calculation that surrounding massif deformation from large-scale blasts at coal opencast less than the permissible deformation:

$$
1,3 \cdot 10-4<2 \cdot 10-4 \text { (for bedrocks) }
$$

$$
\text { 1,3•10-4 }<2 \cdot 10-4 \text { (for coal seam №70) }
$$

\section{CONCLUSIONS}

(1) The obtained results of literature analyses and field measurements shows that mine workings supported by bolts has a high resistance to seismic and shock waves dynamic loadings subjection in the comparison with another types of supporting. Shock waves have a huge affect to elements of anchorage. All sticking elements of anchorage were damaged: mesh-wire lagging, roof covers, sticking parts of bolts. The adhesion and cohesion of the fastening structure of chemical ampules saved after dynamic loadings and high temperature short-pulse.

(2) It has been established that that happen intensive decrease of rocks physical-mechanical properties under water saturation influence. It should be incorporate on stage of support parameters design then mine workings are driving through the water-saturated rocks. It also important to operatively revise the parameters of support in the dripping rocks areas. Particular attention to changes in physical-mechanical properties of rocks should be given during the clearing out and reripping of workings located in the flooding zone and subsequent dehumidification.

(3) It has been established that the oscillations speed and deformations of surrounding massif, the anchor support elements, under the dynamic effects of seismic waves caused by large-scale blasts on the surface or blasts of the methane gas, are lower maximum permissible values. The influ-ence of blasting is expressed in an increase in the speed of displacements of the contour layers of the roof. The speed and values of the displacements of the surrounding massif, in this case, directly de-pend on the intensity and frequency of the blasts. With low-frequency dynamic impacts (blasts of methane gas or coal dust in underground mine workings), the values of the displacements will not have any noticeable effect on the stability of the anchorage and the workings as a whole. If the high-frequency dynamic impacts (mass blasts on the surface) are prolonged from 6 months, the displacement will amount to $40 \mathrm{~mm}$. and will require the development of design and constructive measures to strengthen the support in the workings. The most optimal is the consideration of poten-tial displacements from blasting operations on the surface at the chart support design stage, in order to correct the density of the bolts installation and the length of the bolts.

\section{REFERENCES}

[1] Metodika obsledovanija I ocenki sostojanija podgotovitel'nyh vyrabotok, zakrepljonnyh ankernoj krep'ju I rabotosposobnosti ankernoj krepi po istechenii 5 let jekspluatacii vyrabotok (The survey procedure of mine workings conditions supported by bolts and about bolt work conditions after 5 years exploitation), Prokopevsk, KuzSTU, 2007, $11 \mathrm{p}$.

[2] Instrukcija po raschjotu I primeneniju ankernoj krepi na ugol'nyhm shahtah, (Zaregistrirovano v MinjusteRossii 19.02.2014 №31354) (Technical rules about ancoring calculation and application on coal mines (Recorded by Ministry of Justice of Russia 19.02.2014 №31354))

[3] Instrukcija po raschjotu I primeneniju ankernoj krepi na ugol'nyh shahtah Rossii (Technical rules about ancoring calculation and application on russian coal mines), St. Petersburg, VNIMI, 2000, 70 p.

[4] Radiotehnicheskij pribor podpoverhnostnogo zondirovanija (Georadar "OKO-2"). Tehnicheskoe opisanie, Instrukcija po jekspluatacii (Technical specifications and instruction manual for radio de-vice for subsurface sounding (Georadar "OKO-2"), Ramenskoe, Moskovskaja oblast', 2009. -93 p.

[5] Metodicheskie rekomendacii po raschjotu parametrov stalepolimernyh (stalemineral'nyh) ankerov dlja podveski monorel'sovyh dorog v vyrabotkah, zakrepljonnyh ankernoj krep'ju (Procedural rec-ommendations for bolts parameters calculation which support a monorail railway in mine workings supported by bolts), KuzSTU. - Kemerovo, 2008. - 31 p.

[6] Otchjot po nauchno-issledovatel'skoj rabote "Provesti obsledovanie sostojanija prikonturnyh slojov porod v gornyh vyrabotkah plasta 9 , blok №4, zakrepljonnyh ankernoj krep'ju v uslovijah OAO «Raspadskaja» radiolokacionnym metodom s pomoshh'ju Georadara OKO-2" (Scientific research report "The radio-locating survey of surrounding massif and mining workings state supported by anchoring in conditions of seam № 9 area 4 of Raspadskaia coal mine by means of georadar OKO-2's), Prokop'evsk, KuzSTU, 2014. - 29 p.

[7] N. A. Kutepova, J. I. Kutepov. Izuchenie zakonomernostej razvitija gidrogeomehanicheskih pro-cessov $\mathrm{s}$ cel'ju prognoza deformacij zemnoj poverhnosti pri zatoplenii ugol'nyh shaht (Research after mechanism of development hydro-geomechanical process for prediction of earth surface defor-mations in the conditions of coal mines influenced by flooding), Moscow, MGGU, 2012, pp. 142-154.

[8] The order of Rostechnadzor from 19.11.2013 № 550 «About approval of Federal norms and rules in the field of industrial safety «Regulations for the safe conduct of mining works on deposits prone and dangerous mountain blows».

[9] Esterhuizen G.S., Tulu I. B. Analysis of alternatives for using cable bolts as primary support at two low-seam coal mines. / Conference Record - International Journal Of Mining Science And Tech-nology 2016. pp. 23-30.

[10] Abramovich A., Pudov E., Kuzin E. Prerequisites for the establishment of the automated monitoring system and accounting of the displacement of the roof of underground mines for the improvement of safety of mining work. / The Second International Innovative Mining Symposium (Devoted to Russian Federation Year of Environment). Kemerovo, Russian Federation, November 20 - 22, 2017. - E3C Web of Conferences. - Environment, Energy \&Earth Sciences, volume 21. - 2017.

[11] Shreedharan S., Kulatilake P.H.S.W. Discontinuum-equivalent continuum analysis of the stability of tunnels in a deep coal mine using the distinct element method. / Rock Mechanics And Rock Engineering. Springer Verlag Wien, 49, 5 (2016). pp. 1903-1922.

[12] Tsibaev S. S., Kalinin S. I., Renev A. A., Zorkov D. V. Evaluation of the effect of flood on sur-rounding massif and bolting state. Mining Informational and Analytical Bulletin, Series Mining En-gineerManager's Library, 2015, issue 5, pp. 35-43.

[13] Zorkov D. V., Renev A. A., Tsibaev S. S. The geomechanical research of longwall entry into pre-driven recovery room. Mining Informational and Analytical Bulletin, Series Mining EngineerManager's Library, 2015, issue 4, pp. 12 - 20.

[14] Baskakov V. P. Rekomendacii po sistematicheskomu vizual'nomu kontrolju za rabotoj ankernoj krepi (The bolts control visual methodical recommendation). Prokopevsk, 2013. 39p.

[15] Otchet po nauchno-issledovatel'skoj rabote. Etap 1. «Ocenka sejsmicheskogo voz-dejstviya masso-vyh vzryvov razreza «Zarechnyj» OAO «SUEK-Kuzbass» na podzemnye gornye vyrabotki shahty «Taldinskaya-Zapadnaya-2» OAO «SUEKKuzbass»» (Scientific research report. Stage 1. "As-sessment of the seismic effect of mass blasts of the «Zarechnyi» coal opencast of OJSC «SUEK-Kuzbass» on the underground miny workings of the «Taldinskaya-Zapadnaya-2» coal mine of OJSC «SUEK-Kuzbass»»), Prokop'evsk, KuzSTU, 2013. - 65 p.

[16] Fadeev A. B. Drobyashchee i sejsmicheskoe dejstvie vzryvov na kar'erah (Crushing and seismic action of explosions in open-pit mining), Moscow, Nedra, 1972, 136 p.

[17] Rekomendacii po usileniyu krepi gornyh vyrabotok ankerami v zonah vozdej-stviya dinamicheskih nagruzok (Recommendations for 
strengthening the mine workings support with boltsin areas affected by dynamic loads), KuzNIUI. - Prokopevsk. 